\title{
Yield of upland rice as affected by nitrogen application and seed inoculation with diazotrophic bacteria
}

\author{
Adriano Stephan Nascente*, Maria da Conceição Santana Carvalho \\ Brazilian Agricultural Research Corporation (EMBRAPA), Rice and Beans Research Center, P.O. Box 179, Highway \\ 462, km 12, Santo Antônio de Goiás, State of Goiás, 75.375-000, Brazil
}

\section{*Corresponding author: adriano.nascente@embrapa.br}

\begin{abstract}
The use of nitrogen-fixing diazotrophic bacteria such as Azospirillum spp. could be an important alternative to reduce nitrogen fertilization in upland rice field. The objective of this study was to determine the effect of nitrogen application at topdressing and seed inoculation with strains of Azospirillum spp. on the plant biomass, foliar nutrient concentration, yield components, grain yield and nutrient concentration of grains in upland rice under a no-tillage system. The field experiments were conducted for two growing seasons 2015/2016 and 2016/2017 in the Cerrado Region of Brazil. The experimental design was a complete randomized block in a factorial $4 \times 4$ scheme with three replications. The treatments consisted of inoculated seeds of rice with peat containing the strains of Azospirillum spp. [Azospirillum brasilense 245, Hernaspirillum seropedicae Z94, commercial Azospirillum brasilense (Ab V5 and Ab V6 strains), and without Azospirillum] with four doses of N (0, 40, 80 and $120 \mathrm{~kg} \mathrm{ha}^{-1}$ ) applied as urea at topdressing. The use of diazotrophic bacteria in high level of soil organic matter did not increase yield components, grain yield and nutrients in the leaves and grains of upland rice. Increasing rates of $\mathrm{N}$ increased $\mathrm{N}, \mathrm{P}, \mathrm{K}, \mathrm{Ca}, \mathrm{Mg}, \mathrm{S}, \mathrm{Cu}$ and $\mathrm{Mn}$ in leaves; $\mathrm{N}, \mathrm{P}, \mathrm{Ca}, \mathrm{Cu}$ and $\mathrm{Fe}$ in the grains, biomass, panicle per meter, grain per panicle and grain yield of upland rice. In this sense, the rate of $120 \mathrm{~kg}$ ha ${ }^{-1}$ of $\mathrm{N}$ provided the highest rice grain yield $\left(4,413 \mathrm{~kg} \mathrm{ha}^{-1}\right)$.
\end{abstract}

Keywords: Oryza sativa L., bioagent, nitrogen-fixing, Azospirillum spp., sustainable development.

Abbreviations: Azospirilum 245_Azospirillum brasilenses 245; Z94_Hernaspirillum seropedicae Z94; Comercial Azospirillum_ Azospirillum commercial Ab V5 and Ab V6 strains; M_microorganism; GS_growing season; DAE_days after emergence.

\section{Introduction}

Rice is a crop grown throughout the world, occupying area of more than 164 million hectares in 2014, with an annual production of around 741 million $\mathrm{Mg}$ of paddy grains. China is the world's largest rice producer, contributing about $27.8 \%$ of world production (FAOSTAT, 2017). Globally, Brazil ranks ninth in the production of rice grain, with an estimated production of 12.3 million $\mathrm{Mg}(2016 / 2017)$ in an area of almost 2 million of ha (CONAB, 2017). Rice is a crop that is easily adaptable to different soil and climate conditions. This species has a greatest potential to increase production and to fight against global hunger (Kumar and Ladha, 2011; Guimarães et al., 2013).

Rice production depends mainly on the availability of nitrogen $(\mathrm{N})$, as this is one of the main nutrients responsible for the increase in grain yield (Fageria, 2009; Fidelis et al., 2012; Fageria, 2014). To achieve high grain yields, most producing countries apply high doses of $\mathrm{N}$ fertilizer in rice paddies. In the irrigated rice cultivations of China, they usually use 100 and $200 \mathrm{~kg} \mathrm{ha}^{-1}$ of $\mathrm{N}$. In the Philippines, the best response to $\mathrm{N}$ application is found at around $150 \mathrm{~kg} \mathrm{ha}^{-1}$ of $\mathrm{N}$ (Dobermann et al., 2000). The flooded rice crops in Brazil receive about 90 to $120 \mathrm{~kg} \mathrm{ha}^{-1}$ of $\mathrm{N}$ (Fageria et al., 2003; Hernandes et al., 2010). Upland rice research has pointed out doses ranging up to $140 \mathrm{~kg} \mathrm{ha}^{-1}$ of $\mathrm{N}$ (Fageria, 2014). Rice, along with corn and wheat, consumes about $60 \%$ of the entire $\mathrm{N}$ used in the world (Ladha et al., 2005). The mineral $\mathrm{N}$ is an expensive fertilizer and its excess use can cause damage to the environment, such as the contamination of water sources (Fageria, 2014; Martins et al., 2015). Therefore, it is important that rice management not only reduces production costs but also reduces the environmental pollution levels caused by the use of this fertilizer.

The use of alternative technologies to reduce $\mathrm{N}$ fertilizers in rice crops includes their inoculation with endophytic bacteria (Prakamhang et al., 2009). These bacteria are able to use atmospheric $\mathrm{N}$; thus capable of being assimilated by plants. Biological fixation, performed by diazotrophs, is a process of great importance because it is responsible for the incorporation of considerable amounts of atmospheric $\mathrm{N}$, in both natural ecosystems and in agricultural systems (Guimarães et al., 2010).

Vogel et al. (2013) made a revision about the use of diazotroph bacteria in rice. They reported the benefits related to the morphological aspects of the rice plant including $\mathrm{N}$ accumulation in the plant and in the grain, 
showing increases in root area and plant height, positive contributions related to green and dry mass and the number of panicles. Improvement in grain yield and the partial substitution of $\mathrm{N}$ was also verified. They mentioned that benefits may be attributed to the accumulation of biomass in grains and to photosynthesis justified by the increase in the leaf's $\mathrm{N}$ rate related to the symbiosis with Azospirillum brasilense in the root system area.

According to Guimarães et al. (2010), who studied seeds of rice cultivars IR42 and IAC4440 inoculated with peat containing strains ZAE94 (BR 11417 - Herbaspirillum seropedicae and M130 (BR 11340 - Burkholderia sp.), there were positive effects of inoculation in both studied cultivars in all evaluated parameters, mainly in the accumulation of nitrogen in plants and grains. Sabino et al. (2012) reported that the inoculation of the strains of Diazotrophic together with the application of $50 \mathrm{~kg} \mathrm{~N} \mathrm{ha}^{-1}$ led to the largest accumulations of biomass in seedlings of rice cultivars IR42 and IAC4440. Kuss et al. (2007) observed that Azospirillum brasilense can provide greater increases in rice cultivar IRGA - 420. Gitti et al. (2012) showed that the inoculation of rice seeds with Azospirillum brasilense was effective to provide increases in leaf $\mathrm{N}$ content, number of panicles per $\mathrm{m}^{2}$ and dry biomass and the mass of 100 grains in upland rice. Guimarães and Baldani (2013) pointed the most promising results towards the IAC4440 cultivar, with increases of up to $54 \%$ in grain production due to the inoculation of diazotrophic bacteria.

However, despite the researches conducted in this subject, there are still few studies under field conditions, especially in rainfed cultures and fewer in the Cerrado region. We had the hypothesis that use of $\mathrm{N}$ rates increase content of nutrients in leaves and grains, biomass, yield components and grain yield or rice and the use of diazotrophic bacteria would potentiate the effect of $\mathrm{N}$ rates in upland rice development. Therefore, the objective was to determine the effect of nitrogen application at topdressing and seed inoculation with strains of Azospirillum spp. on plant biomass, foliar nutrient concentration, yield components, grain yield and nutrient concentration in grains of upland rice under no-tillage systems in a Cerrado Region.

\section{Results}

\section{Nutrient content in rice leaves}

There was no effect of microorganism types on the nutrient content in rice shoots (Table 1). The only exception was iron, where Hernaspirillum Z94 provided higher content in rice leaves when compared with Azospirillum 245. Regarding N rates, there were single effects on $\mathrm{N}, \mathrm{P}, \mathrm{Ca}$ and $\mathrm{Mg}$ content in rice shoots. Nitrogen and $\mathrm{Ca}$ had linear trend with increasing of $\mathrm{N}$ rates (Fig. 1). Phosphorus and $\mathrm{Mg}$ showed quadratic trend with increasing $\mathrm{N}$ rates.

There was interaction between $\mathrm{N}$ rates and diazotrofic bacteria types on $\mathrm{K}, \mathrm{S}, \mathrm{Cu}$ and $\mathrm{Mn}$ concentration in rice leaves (Table 1). Commercial Azospirillum allowed higher K, $\mathrm{S}, \mathrm{Cu}$ and $\mathrm{Mn}$ concentration to absorb due to increased $\mathrm{N}$ rates (Fig.2). Hernaspirillum 94 acted less than Commercial Azospirillum, but also provided an increase in the $\mathrm{K}, \mathrm{Cu}$ and $\mathrm{Mn}$ concentration of rice leaves, while $S$ concentration was not significant. Azospirillum 245 provided a reduction in the content of $\mathrm{N}$ and $\mathrm{Mn}$ in rice leaves, an increase in the $\mathrm{S}$ concentration and no significant effect on $\mathrm{Cu}$ concentration. There was no difference in any macro and micronutrients concentrations in rice leaf upon treatments of diazotrofic bacteria, compared to the control (no bacteria treatment) (Table 1). The only exception was the $P$ concentration in plants treated by Commercial Azospirillum that differed from the control treatment.

Nitrogen, $\mathrm{K}, \mathrm{Ca}, \mathrm{S}, \mathrm{Cu}$ and $\mathrm{Mn}$ content in rice leaves was higher in growing season 2016/2017 than in growing season 2015/2016 (Table 1). On the other hand, P, Mg, Fe and Zn was higher in 2015/2016 than in 2016/2017. There were no differences between nutrient concentration in rice leaves, when treated with bacteria and the control treatment

\section{Shoot dry biomass, yield components and grain yield}

Shoot dry biomass, number of panicle per meter, number of grains per panicle, mass of 1000 grains and grain yield was not affected by bacteria type (Table 2). The control treatment did not differ by any of these variables.

Regarding $\mathrm{N}$ rates, there were single effects on shoot dry biomass, number of panicle per meter, number of grains per panicle, mass of 1000 grains and grain yield (Table 2). All these variables were adjusted by linear equation (Fig. 3). The only exception was number of panicle per meter that fit to a quadratic equation. Shoot dry biomass, number of panicle per meter, number of grains per panicle and grain yield increased values upon increasing $\mathrm{N}$ rates. On the other hand, mass of 1000 grains reduced values after increasing $\mathrm{N}$ rates. In the growing season 2016/2017, shoot dry biomass, number of panicle per meter, number of grains per panicle and grain yield was higher in growing season 2015/2016 (Table 2). Besides, there were no differences among these variables, compared to the control treatment.

\section{Nutrients concentrations on rice grains}

There was no effect of bacteria on the $N, P, K, M g, F e, M n$ and $\mathrm{Zn}$ concentration in the rice grains (Table 3 ). There was single effect of $\mathrm{N}$ rates on $\mathrm{N}, \mathrm{P}, \mathrm{Cu}$ and Fe concentration on rice grains. Nitrogen, $\mathrm{P}, \mathrm{Cu}$ and $\mathrm{Fe}$ was fit to a linear equation increasing values due to increasing $\mathrm{N}$ rates (Fig.4). Commercial Azospirillum increased the $\mathrm{Cu}$ content in rice grains, differing from Azospirillum 245. On the other hand, Ca content in rice grains when treated with Azospirillum 245 was higher than the other diazotrophic bacteria.

Concentrations of $\mathrm{N}, \mathrm{P}, \mathrm{K}, \mathrm{Ca}, \mathrm{Mg}$ and $\mathrm{Zn}$ in rice grains was higher in growing season 2015/2016 than in growing season 2016/2017 (Table 3). The content of $\mathrm{Cu}$ and $\mathrm{Mn}$ was higher in 2016/2017 than in 2015/2016. There was no difference between nutrient concentration in rice grains, compared with bacteria and the control treatment. 
Table 1. Effects of Azospirillum brasilenses 245 (Azospirilum 245), Hernaspirillum seropedicae Z94 (Z94) and Azospirillum commercial Ab V5 and Ab V6 strains (Comercial Azospirillum) on nutrient content in rice leaves at full flowering stage in Santo Antonio de Goias, growing seasons 2015/16 and 2016/17.

\begin{tabular}{|c|c|c|c|c|c|c|c|c|c|c|}
\hline Factors & $\mathrm{N}$ & $\mathrm{P}$ & $\mathrm{K}$ & $\mathrm{Ca}$ & $\mathrm{Mg}$ & $\mathrm{S}$ & $\mathrm{Cu}$ & $\mathrm{Fe}$ & $\mathrm{Mn}$ & $\mathrm{Zn}$ \\
\hline Microorganism (M) & \multicolumn{6}{|c|}{ 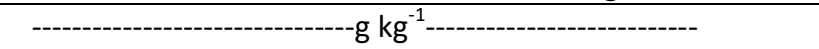 } & \multicolumn{4}{|c|}{---------------'mg kg } \\
\hline Azospirillum 245 & 22.15 & 2.71 & 18.79 & 3.28 & 2.31 & 2.82 & 7.08 & $96 \mathrm{~b}$ & 88 & 44.17 \\
\hline Hernaspirillum Z94 & 22.45 & 2.77 & 19.14 & 3.42 & 2.35 & 2.84 & 7.39 & 126 a & 93 & 43.50 \\
\hline Commercial Azospirillum & 22.56 & $2.97^{+}$ & 18.95 & 3.29 & 2.29 & 2.84 & 7.36 & $116 a b$ & 94 & 47.82 \\
\hline Control & 21.92 & 2.63 & 19.25 & 3.40 & 2.35 & 2.74 & 7.54 & 124 & 96 & 49.66 \\
\hline \multicolumn{11}{|l|}{ Growing season } \\
\hline $2015 / 2016$ & $.5 .16 \mathrm{~b}$ & $3.45 \mathrm{a}$ & $17.79 \mathrm{~b}$ & $2.50 \mathrm{~b}$ & $2.68 \mathrm{a}$ & $2.10 \mathrm{~b}$ & $6.92 \mathrm{~b}$ & $156 \mathrm{a}$ & $75 \mathrm{~b}$ & $70.42 \mathrm{a}$ \\
\hline $2016 / 2017$ & $9.62 \mathrm{a}$ & $2.18 \mathrm{~b}$ & $20.13 \mathrm{a}$ & $4.16 \mathrm{a}$ & $1.96 \mathrm{~b}$ & $3.56 \mathrm{a}$ & $7.63 \mathrm{a}$ & $69 \mathrm{~b}$ & $108 \mathrm{a}$ & $19.91 \mathrm{~b}$ \\
\hline Factors & \multicolumn{10}{|c|}{ ANOVA (F probability) } \\
\hline Microorganism (M) & 0.6931 & 0.2007 & 0.8439 & 0.3924 & 0.6710 & 0.9212 & 0.1199 & 0.0424 & 0.5268 & 0.3337 \\
\hline Nitrogen rates $(\mathrm{N})$ & 0.0004 & 0.0006 & 0.0104 & 0.0011 & 0.0060 & 0.0013 & 0.1307 & 0.8712 & 0.0003 & 0.4146 \\
\hline Growing season (GS) & $<0.001$ & $<0.001$ & $<0.001$ & $<0.001$ & $<0.001$ & $<0.001$ & $<0.001$ & $<0.001$ & $<0.001$ & $<0.001$ \\
\hline $\mathrm{M} * \mathrm{~N}$ & 0.4131 & 0.4691 & $<0.001$ & 0.0936 & 0.3156 & 0.0059 & 0.0073 & 0.0543 & 0.0191 & 0.2824 \\
\hline$M * G S$ & 0.7752 & 0.1070 & 0.3721 & 0.6673 & 0.9366 & 0.3660 & 0.2634 & 0.0510 & 0.4160 & 0.3140 \\
\hline $\mathrm{N} * \mathrm{GS}$ & 0.5018 & 0.0519 & 0.0569 & 0.6098 & 0.4915 & 0.5119 & 0.5573 & 0.6808 & 0.3699 & 0.4136 \\
\hline$M * N * G S$ & 0.4624 & 0.3230 & 0.0529 & 0.1961 & 0.1088 & 0.1642 & 0.0571 & 0.0633 & 0.0523 & 0.2536 \\
\hline
\end{tabular}

*Means followed by the same letter do not differ by Tukey test. Means followed by this signal + do not differed from the control by the Dunnett's test.
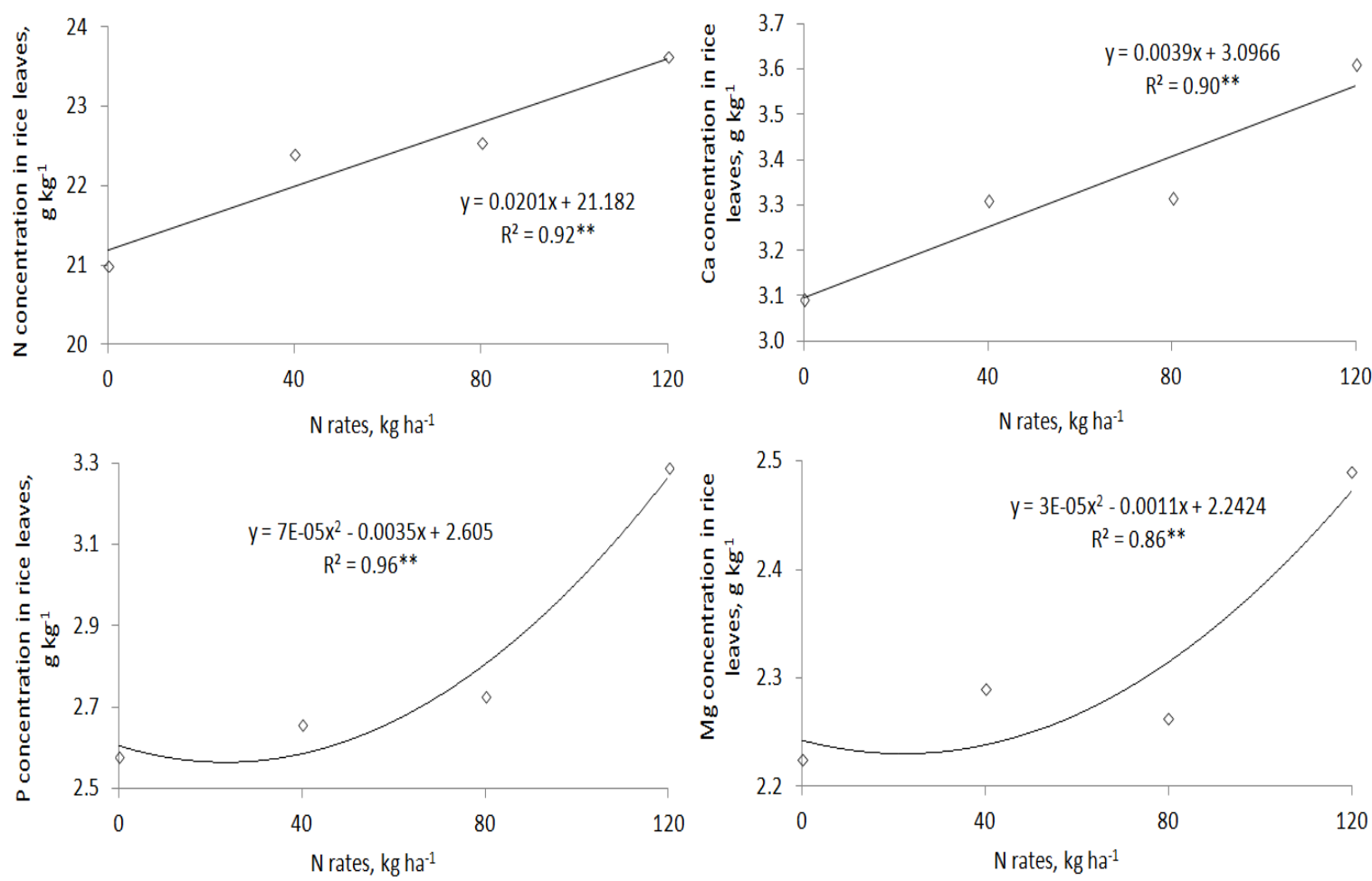

Fig 1. Nitrogen, $\mathrm{P}, \mathrm{Ca}$ and $\mathrm{Mg}$ concentration in rice leaves as a function of $\mathrm{N}$ rates applied at topdressing fertilization (18 DAE). Santo Antônio de Goiás, growing season 2015/2016. 
Table 2. Effects of Azospirillum brasilenses 245 (Azospirilum 245), Hernaspirillum seropedicae Z94 (Z94) and Azospirillum commercial Ab V5 and Ab V6 strains (Comercial Azospirillum) as affecting plant biomass (PB), number of panicles per meter (NPM), number of grains per panicle (NGP), mass of 1000 grains (1000M) and grain yield (GY) of upland rice in growing seasons 2015/16 and 2016/17 Santo Antonio de Goias.

\begin{tabular}{|c|c|c|c|c|c|}
\hline Factors & PB & NPM & NGP & $1000 \mathrm{M}$ & GY \\
\hline Microorganism (M) & $\mathrm{g} \mathrm{m}^{-2}$ & unit & unit & $\mathrm{g}$ & $\mathrm{kg} \mathrm{ha}^{-1}$ \\
\hline Azospirillum 245 & 209 & 92 & 123 & 23.61 & 3762 \\
\hline Hernaspirillum Z94 & 207 & 95 & 128 & 23.47 & 3735 \\
\hline Commercial Azospirillum & 189 & 91 & 130 & 23.26 & 3958 \\
\hline Control & 202 & 95 & 128 & 24.25 & 3820 \\
\hline \multicolumn{6}{|l|}{ Growing season } \\
\hline $2015 / 2016$ & $178 \mathrm{~b}$ & $88 \mathrm{~b}$ & $110 \mathrm{~b}$ & 23.49 & $3257 b$ \\
\hline $2016 / 2017$ & $226 \mathrm{a}$ & $98 \mathrm{a}$ & $144 \mathrm{a}$ & 23.41 & $4380 \mathrm{a}$ \\
\hline Factors & \multicolumn{5}{|c|}{ ANOVA (F probability) } \\
\hline Microorganism (M) & 0.0814 & 0.7305 & 0.3955 & 0.6451 & 0.4370 \\
\hline Nitrogen rates $(\mathrm{N})$ & 0.0044 & 0.0181 & 0.0495 & 0.0310 & $<0.001$ \\
\hline Growing season (GS) & $<0.001$ & 0.0053 & $<0.001$ & 0.8009 & $<0.001$ \\
\hline$M * N$ & 0.0503 & 0.7583 & 0.6921 & 0.3441 & 0.9503 \\
\hline$M * G S$ & 0.2109 & 0.7930 & 0.8881 & 0.7229 & 0.2870 \\
\hline $\mathrm{N} * \mathrm{GS}$ & 0.1660 & 0.4243 & 0.3977 & 0.7130 & 0.5060 \\
\hline$M * N * G S$ & 0.1636 & 0.8363 & 0.9071 & 0.8280 & 0.4086 \\
\hline
\end{tabular}
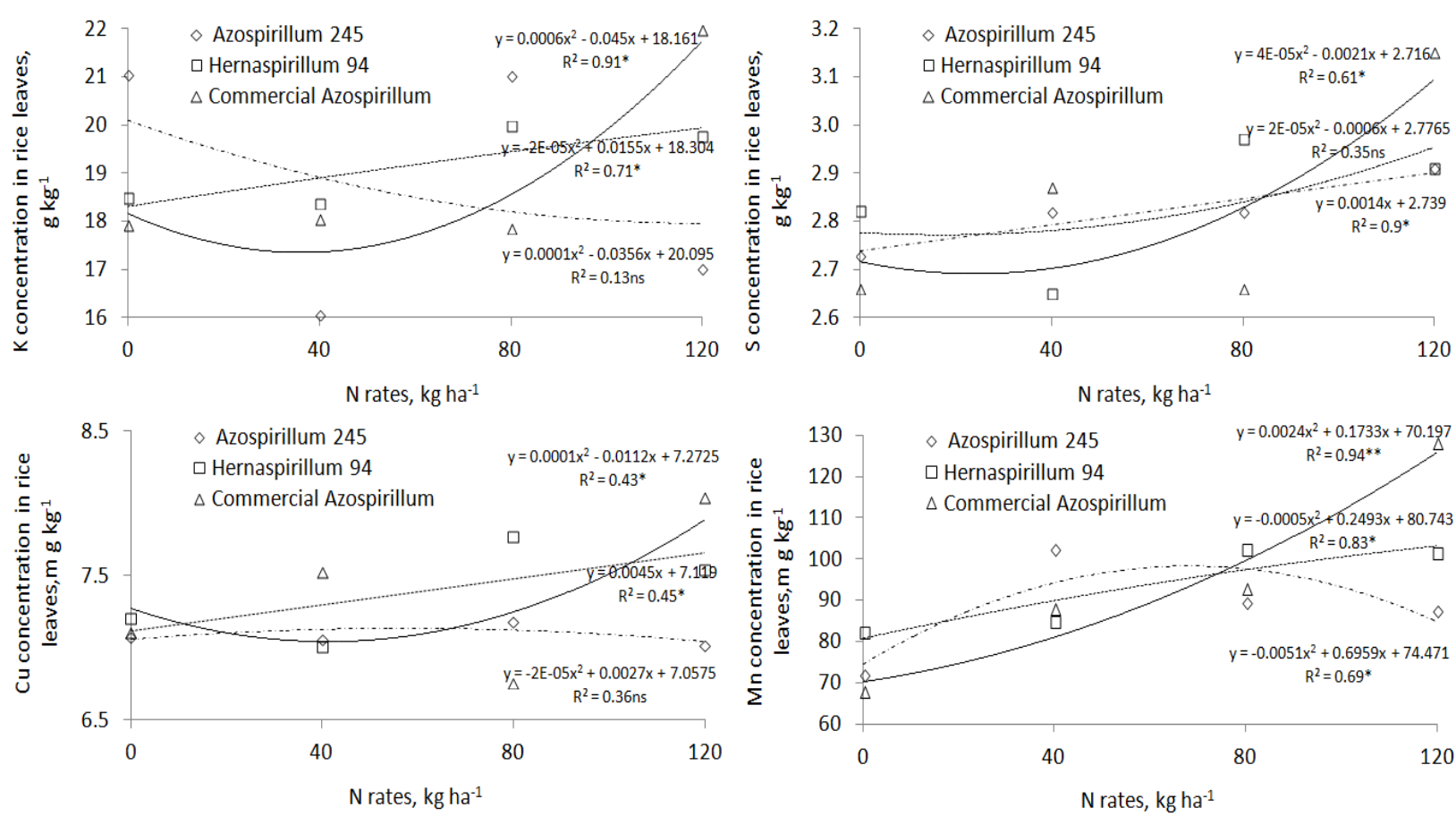

Fig 2. Potassium, $\mathrm{S}, \mathrm{Cu}$ and $\mathrm{Mn}$ concentration on rice leaves as a function of $\mathrm{N}$ rates applied at topdressing fertilization (18 DAE) and diazotrophic bacteria. Santo Antônio de Goiás, growing season 2015/2016. 
Table 3. Effects of Azospirillum brasilenses 245 (Azospirilum 245), Hernaspirillum seropedicae Z94 (Z94) and Azospirillum commercial Ab V5 and Ab V6 strains (Comercial Azospirillum) as affecting nutrient content in rice grains. Santo Antonio de Goias, growing seasons 2015/16 and 2016/17.

\begin{tabular}{|c|c|c|c|c|c|c|c|c|c|}
\hline Factors & $\mathrm{N}$ & $\mathrm{P}$ & $\mathrm{K}$ & $\mathrm{Ca}$ & $\mathrm{Mg}$ & $\mathrm{Cu}$ & $\mathrm{Fe}$ & $\mathrm{Mn}$ & $\mathrm{Zn}$ \\
\hline Microorganism (M) & \multicolumn{5}{|c|}{--or } & \multicolumn{4}{|c|}{-----------mg kg ${ }^{-1}----------$} \\
\hline Azospirillum 245 & 14.17 & 3.29 & 2.64 & $0.33 \mathrm{a}$ & 1.48 & $4.27 \mathrm{~b}$ & 22.60 & 27.09 & 38.63 \\
\hline Hernaspirillum Z94 & 14.13 & 3.25 & 2.57 & $0.31 b$ & 1.47 & $4.37 \mathrm{ab}$ & 26.10 & 26.23 & 38.31 \\
\hline Commercial Azospirillum & 14.81 & 3.24 & 2.74 & $0.32 \mathrm{~b}$ & 1.46 & $4.41 \mathrm{a}$ & 26.66 & 28.82 & 38.50 \\
\hline Control & 14.02 & 3.25 & 2.62 & 0.32 & 1.47 & 4.42 & 24.25 & 26.63 & 38.35 \\
\hline \multicolumn{10}{|l|}{ Growing season } \\
\hline $2015 / 2016$ & $15.93 \mathrm{a}$ & $3.77 \mathrm{a}$ & $2.82 \mathrm{a}$ & $0.33 \mathrm{a}$ & $1.61 \mathrm{a}$ & $3.64 \mathrm{~b}$ & 23.91 & $24.87 b$ & $40.07 a$ \\
\hline $2016 / 2017$ & $12.81 \mathrm{~b}$ & $2.74 \mathrm{~b}$ & $2.48 \mathrm{~b}$ & $0.31 \mathrm{~b}$ & $1.33 \mathrm{~b}$ & $5.07 \mathrm{a}$ & 26.33 & 29.89 a & $36.89 \mathrm{~b}$ \\
\hline Factors & \multicolumn{9}{|c|}{ ANOVA (F probability) } \\
\hline Microorganism (M) & 0.1149 & 0.7479 & 0.5686 & 0.0066 & 0.7817 & 0.0418 & 0.5496 & 0.1309 & 0.8943 \\
\hline Nitrogen rates $(\mathrm{N})$ & 0.0316 & 0.0075 & 0.1787 & 0.4753 & 0.0572 & 0.0003 & 0.0319 & 0.3840 & 0.5383 \\
\hline Growing season (GS) & $<0.001$ & $<0.001$ & 0.0117 & $<0.001$ & $<0.001$ & $<0.001$ & 0.4600 & $<0.001$ & $<0.001$ \\
\hline$M * N$ & 0.6342 & 0.9392 & 0.8288 & 0.0556 & 0.9570 & 0.0578 & 0.3784 & 0.6488 & 0.2935 \\
\hline$M^{*} G S$ & 0.7892 & 0.7964 & 0.8882 & 0.0818 & 0.9200 & 0.5636 & 0.4126 & 0.2467 & 0.3155 \\
\hline $\mathrm{N}^{*} \mathrm{GS}$ & 0.9193 & 0.5788 & 0.5990 & 0.0576 & 0.4219 & 0.0521 & 0.2462 & 0.5490 & 0.6169 \\
\hline$M * N * G S$ & 0.9232 & 0.3187 & 0.6858 & 0.1111 & 0.5480 & 0.0501 & 0.4908 & 0.0411 & 0.7505 \\
\hline
\end{tabular}

*Means followed by the same letter do not differ by Tukey test. Means followed by this signal + do not differed from the control by the Dunnett's test.
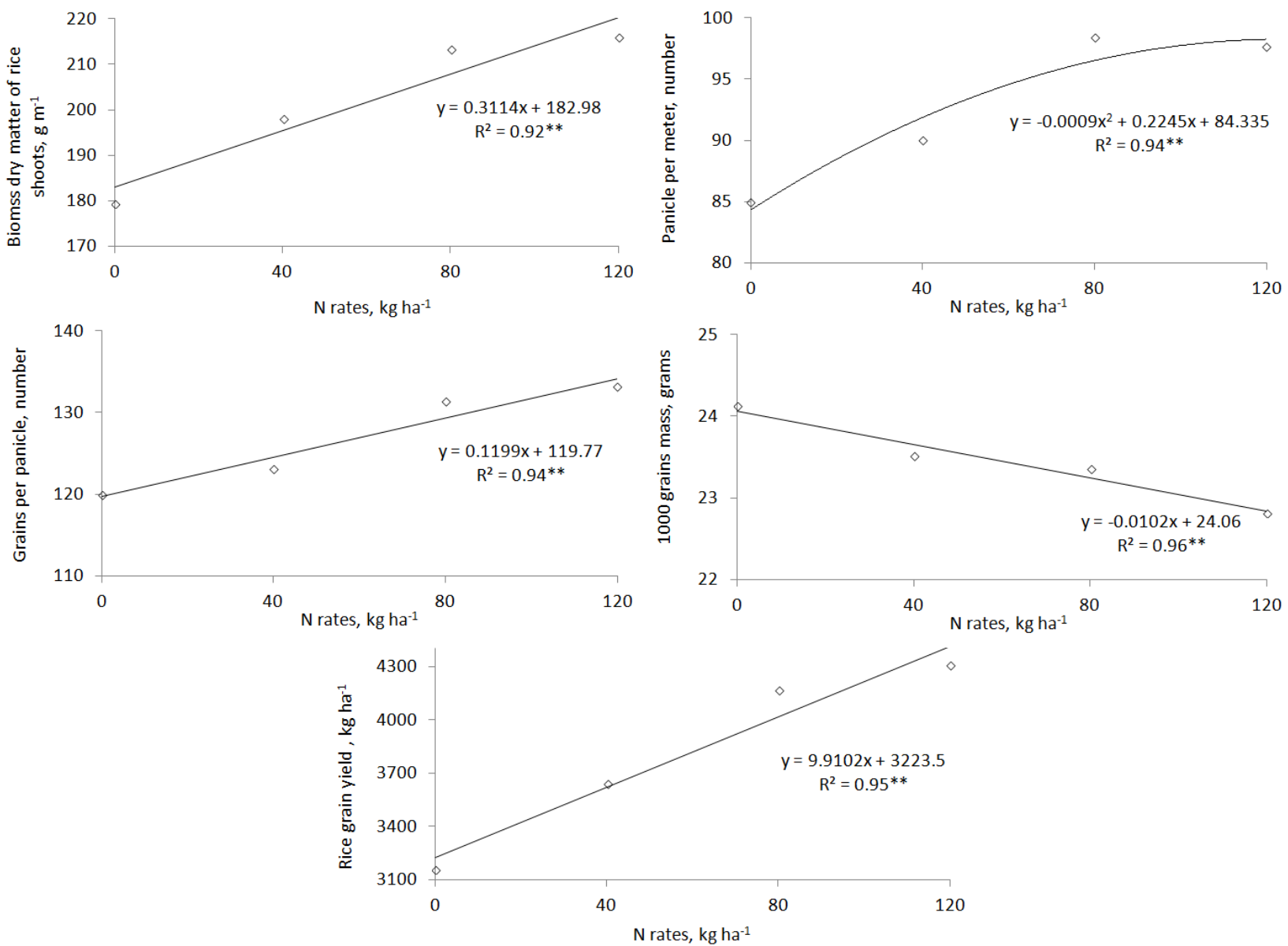

Fig 3. Shoot dry biomass, number of panicles per meter, number of grains per panicle, mass of 1000 grains and grain yield of upland rice as a function of N rates applied at topdressing fertilization (18 DAE). Santo Antônio de Goiás, growing season 2015/2016. 
Table 4. Chemical and physical properties of the soil at the beginning of the trial.

\begin{tabular}{|c|c|c|c|c|c|c|c|}
\hline \multicolumn{8}{|c|}{ Growing season $2015 / 2016$} \\
\hline Depth & $\mathrm{Ca}$ & $\mathrm{Mg}$ & $\mathrm{H}+\mathrm{Al}$ & $\mathrm{SOM}^{\mathrm{a}}$ & $\mathrm{P}$ & $\mathrm{K}$ & $\mathrm{pH}\left(\mathrm{H}_{2} \mathrm{O}\right)$ \\
\hline (m) & \multicolumn{3}{|c|}{ - } & $\mathrm{g} \mathrm{dm}^{-3}$ & \multicolumn{3}{|c|}{----mg dm ${ }^{-3}---$} \\
\hline $0-0.20$ & 18.0 & 13.3 & 24.0 & 32.7 & 9.9 & 101.3 & 5.9 \\
\hline Depth & $\mathrm{Cu}$ & $\mathrm{Zn}$ & $\mathrm{Fe}$ & $\mathrm{Mn}$ & Clay & Silt & Sand \\
\hline (m) & \multicolumn{3}{|c|}{---------------mg dm'-3 } & & \multicolumn{3}{|c|}{----------g kg ${ }^{-1}$} \\
\hline $0-0.20$ & 0.8 & 4.6 & 20.5 & 10.1 & 480 & 226 & 294 \\
\hline \multicolumn{8}{|c|}{ Jrowing season 2016/2017 } \\
\hline Depth & $\mathrm{Ca}$ & $\mathrm{Mg}$ & $\mathrm{H}+\mathrm{Al}$ & $\mathrm{SOM}^{\mathrm{a}}$ & $\mathrm{P}$ & $\mathrm{K}$ & $\mathrm{pH}\left(\mathrm{H}_{2} \mathrm{O}\right)$ \\
\hline (m) & \multicolumn{3}{|c|}{ - $\mathrm{mmol}_{\mathrm{c}} \mathrm{dm}^{-3}$} & $\mathrm{~g} \mathrm{dm}^{-3}$ & \multicolumn{3}{|c|}{$----m g d^{-3}---$} \\
\hline $0-0.20$ & 10.7 & 10.9 & 31.0 & 42.22 & 12.6 & 97 & 5.5 \\
\hline $\begin{array}{l}\text { Depth } \\
\text { (m) }\end{array}$ & $\mathrm{Cu}$ & $\begin{array}{l}\mathrm{Zn} \\
\mathrm{mg} \mathrm{dn}\end{array}$ & $\mathrm{Fe}$ & $\mathrm{Mn}$ & Clay & Silt & Sand \\
\hline $0-0.20$ & 1.2 & 8.1 & 31.0 & 12.2 & 520 & 180 & 300 \\
\hline
\end{tabular}

a SOM - soil organic matter.
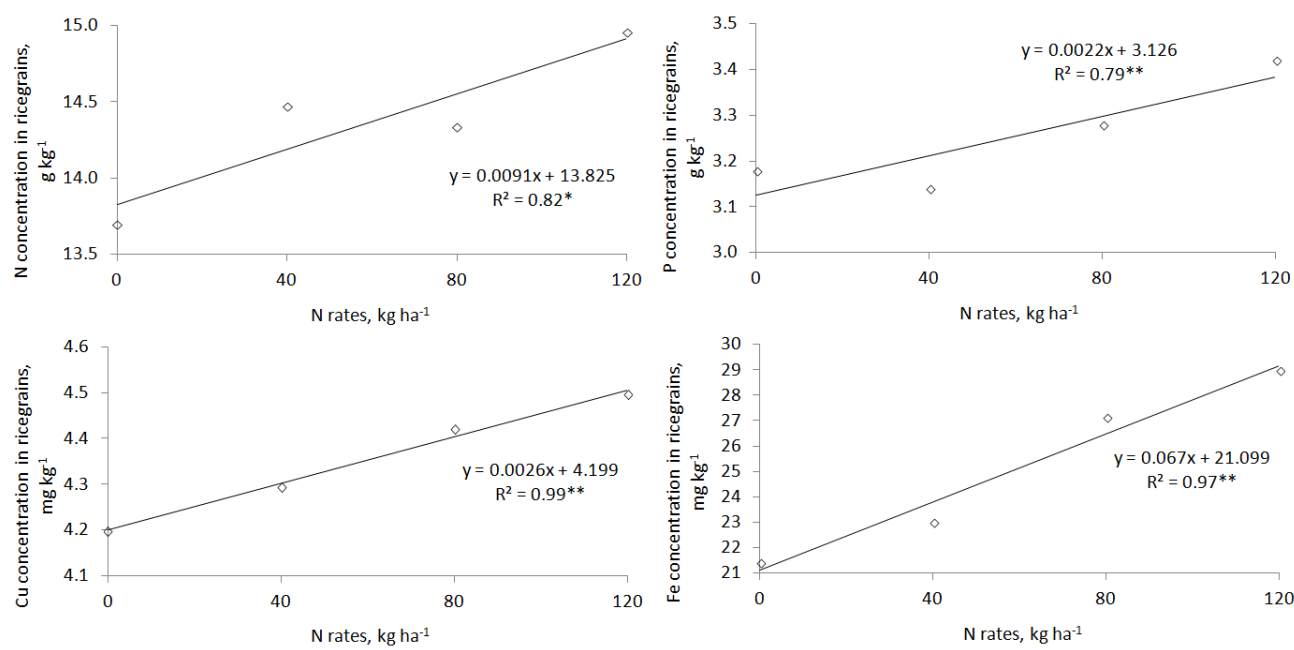

Fig 4. Nitrogen, $P, M g$ and Fe concentration on rice grains as a function of $\mathrm{N}$ rates applied at topdressing fertilization (18 DAE). Santo Antônio de Goiás, growing season 2015/2016.
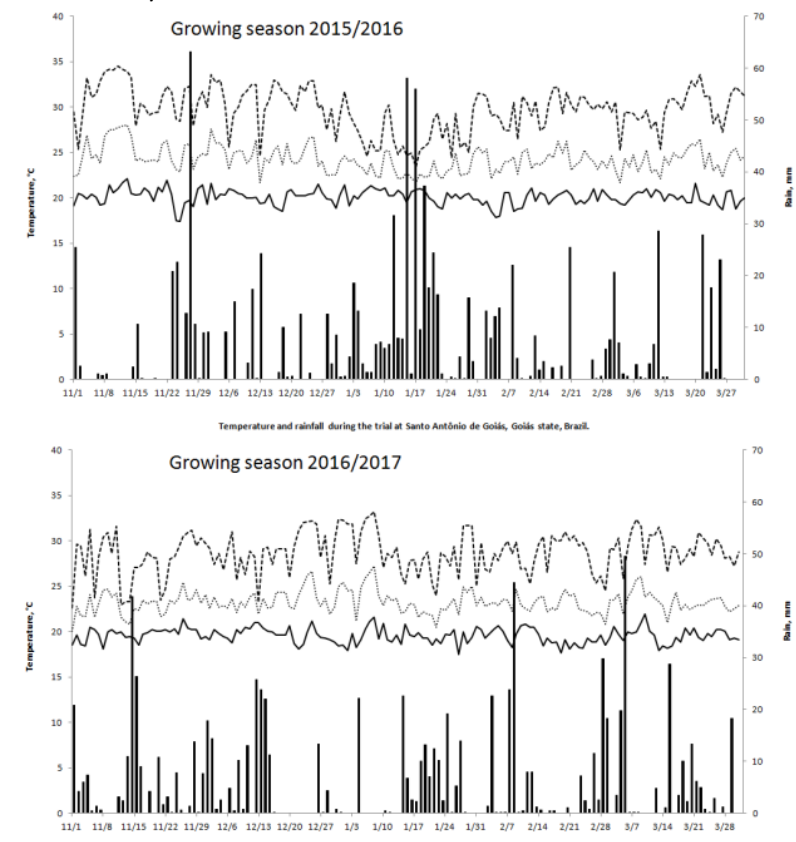

Fig 5. Maximum ( $T$ maximum), minimum ( $T$ minimum) and average ( $T$ average) temperatures and rainfall during the trial period of upland rice grown under no-tillage system in the experimental fields of Santo Antônio de Goiás/Brazil in the 2015/16 and 2016/17 growing seasons. 


\section{Discussion}

Rice grain yield was higher in the growing season 2016/2017 than $2015 / 2016$, which could be related to the soil fertility (Sousa and Lobato, 2004) and rainfall distribution (Table 1). The total rainfall for the growing season 2015/2016 was $692.8 \mathrm{~mm}$, which was a little more than growing season 2016/2017 with a total rainfall of $678.2 \mathrm{~mm}$. However, there was less rain in the period of flowering to grain filling in the growing season 2015/2016 (195.4 mm) than in the growing season 2016/2017 (370.0 mm). According to Heinemann (2008) the negative effects of water stress can be intensified if there is restriction to root growth, one of the most critical phases being flowering.

The effects of beneficial microorganisms on plants can be direct, indirect and both at the same time (Pérez-Montaño et al., 2014). As indirect effects, the microorganisms can provide greater efficiency in the gas exchange process (Nascente et al., 2017) and/ or increasing the uptake of water and minerals (Pérez-García et al. 2011; Zhang et al. 2011; Nascente et al., 2017). In our study, commercial Azospirillum provided increases in $\mathrm{P}$ content in rice leaves and differed from the control treatment (Table 1). Besides, commercial Azospirillum allowed increases in $\mathrm{Cu}$ content in rice grains and $\mathrm{Ca}$ content in rice grains when treated with Azospirillum 245.

Nitrogen rates with diazotrophic bacteria provided differences in the $\mathrm{K}, \mathrm{S}, \mathrm{Cu}$ and $\mathrm{Mn}$ content in rice plants. The commercial Azospirillum provided increases in all these nutrients, after increasing $N$ rates. In this sense, this diazotrophic bacteria showed more promising that the others. However, Hernaspirillum Z94 also increased these nutrient contents and allowed higher values than Azospirillum 245.

Nitrogen, $\mathrm{P}, \mathrm{Ca}$ and $\mathrm{Mg}$ increased their content in rice leaves as increased $N$ rates. Kuss et al. (2007) also reported increases in $\mathrm{N}$ content in rice leaves and observed that this increases is linked to the rates of $\mathrm{N}$ applied at topdressing. So, the increase of $\mathrm{N}$ rates increased the availability of this nutrient and contributed to linear increase of plant tissue (Hernandes et al., 2010; Gitti et al., 2012; Lopes et al., 2013). According to Fageria (2014) and Reis et al. (2017) the $N$ and $\mathrm{P}$ are part of several structures in the plant and usually increasing the levels of one nutrient in rice leaves implies the increase of the other. The increased content of $\mathrm{Ca}$ and $\mathrm{Mg}$ upon increasing $\mathrm{N}$ rates could be due to more $\mathrm{N}$ uptake by rice plants. The plants also need to uptake more nutrients, such as Ca that is important for the cell wall and $\mathrm{Mg}$ to the chlorophyll (Fageria, 2014).

The mass of 1000 grains was reduced due to increased $\mathrm{N}$ rates. This could be attributed to increasing the number of grains per panicle due to a tendency to reduce the mass of grains (Santos et al., 2006). The rates of $\mathrm{N}$ increased biomass dry matter, number of panicle, grains per panicle and as a result grain yield. Number of panicle per meter and grains per panicle are yield components that directly influence in the grain yield (Yoshida, 1981). Nitrogen is a structure nutrient and it is expected that its increases provide increases in plant development, yield components and grain yield (Fageria, 2014). Hernandes et al. (2010), Fageria et al. (2011), Nascente and Lanna (2016) and Fageria (2014) reported that nitrogen fertilization in rice is directly related to increased crop productivity.
Increasing $\mathrm{N}$ rates provided increases in $\mathrm{N}, \mathrm{P}, \mathrm{Cu}$ and $\mathrm{Fe}$ content in rice grains. Also Zaki (2016) showed that increasing $\mathrm{N}$ rates increased $\mathrm{N}, \mathrm{P}$ and $\mathrm{Fe}$ in the grains. According to Ahemad and Kibret (2014), fertilization can influence effects of diazotrophic bacteria on plants. On the other hand, Fageria (2014) stated that increasing N rates can also enhance grain nutrient content.

Overall, in our trial it was observed that diazotrophic bacteria did not affect upland rice development. This could be because of high level of soil organic matter (SOM) in the soil (Table 4). It is likely that high level of SOM can inhibit bacteria activities to prevent more $\mathrm{N}$ supply to the rice plants. Also Pereira et al. (1988), Guimarães et al. (2010), Gitti et al. (2012) reported that the use of diazotrophic bacteria did not affect rice grain yield. This negative result of using diazotrophic bacteria could be justified by many other factors involving in production such as influence of variability in bacteria and plant, phenological stage, characteristics of the soil, performance of other macrobiotic components, competitiveness, among others factors, etc. (Sturz and Nowak, 2000). In this way, studies should be done to elucidate the interactions between diazotrophic bacteria with other factors to allow using these bacteria in effective way.

According to Silva et al. (2016), in cereals, $\mathrm{N}$ recovery efficiency at a global level is reported to be less than $40 \%$. This low recovery efficiency could be associated with nutrient losses by leaching, denitrification, volatilization and soil erosion (Fageria, 2014). Thus, to achieve maximum benefits in terms of fertilizer savings and better upland rice growth, we have to develop new technologies to introduce diazotrophic bacteria and reduce $\mathrm{N}$ fertilization when aiming a sustainable agriculture.

\section{Materials and methods}

\section{Site description}

The experiments were conducted at the Capivara Farm of the Embrapa Rice and Beans Unit, which is located in Santo Antônio de Goiás, GO, Brazil, at 16²8'00"S and 4917'00"W and at an elevation of $823 \mathrm{~m}$. The climate is of a tropical savanna nature and is considered Aw according to its Köppen classification. There are two well-defined seasons: a usually dry season from May to September (autumn/winter) and a wet season from October to April (spring/summer). The average annual rainfall is between 1500 and $1700 \mathrm{~mm}$, and the average annual temperature is $22.7^{\circ} \mathrm{C}$, ranging annually from $14.2^{\circ} \mathrm{C}$ to $34.8^{\circ} \mathrm{C}$. During the period of this study, the temperature and the amount of rainfall data were recorded (Fig. 5).

The soil is classified as a clay loam (kaolinitic, thermic Typic Haplorthox) acidic soil. Prior to the study, chemical and physical analyses were performed for the initial characterization of the area in November 2015 and 2016 (Table 4). Chemical and physical analyses were performed according to the methodology proposed by Claessen (1997). The experimental area had been previously cultivated in a crop-livestock integration style using a no-tillage system for seven consecutive years, followed by a crop rotation program of soybean (summer), rice (summer) and irrigated common bean (winter), corn + Brachiaria (summer), and two years of grazing pasture. The installation of experiments was 
conducted in plots, where the upland rice was the crop to be grown following the established program of crop rotation.

\section{Experimental design and treatments}

Trials were conducted under rainfed conditions using the Clearfield genotype of rice (07SEQCL441 CL), which is resistant to the Imazapyr + Imazapic herbicide (Rangel et al., 2010. Trials were arranged in a factorial, randomized, complete block design with three replications during two growing seasons (2015/16 and 2016/17) in different areas. The treatments consisted of inoculated seeds of rice with peat containing the strains of Azospirillum spp. (Azospirillum brasilense 245, Hernaspirillum seropedicae Z94, commercial Azospirillum brasilense (Ab V5 and Ab V6 strains), and without Azospirillum) with four doses of N (0, 40, 80 and 120 $\mathrm{kg} \mathrm{ha}^{-1}$ ) applied at topdressing fertilization, as urea, broadcasted on the soil surface of the plots. The plots had dimensions of $3.5 \mathrm{~m} \times 6 \mathrm{~m}$. The usable area of the plot was composed of the four central rows of rice, disregarding one row and $0.50 \mathrm{~m}$ to the front side of each plot.

\section{Rice crop management}

Cover crops were desiccated with application of glyphosate (1.8 $\mathrm{kg} \mathrm{ha}^{-1}$ acid equivalent) 30 days before sowing of the upland rice. The sowing was performed mechanically using 200 seeds per $\mathrm{m}^{-2}$ of rice. The seed was sown on December $15^{\text {th }}, 2015$ and on November $11^{\text {th }}, 2016$. Shortly before sowing the rice, seed inoculation was carried out with diazotrophic bacteria, according to each treatment. Inoculation was performed in the shade and 216 viable cells per gram of each product were used, using a dose of $200 \mathrm{~g}$ of inoculums per $25 \mathrm{~kg}$ of seed. Rice plant emergence occurred five days after sowing for the growing seasons. The base fertilization was calculated according to the soil's chemical characteristics and followed the recommendations of Sousa and Lobato (2004) and applied in the sowing furrows. Therefore, the sowing fertilization was $20 \mathrm{~kg} \mathrm{ha}^{-1}$ of $\mathrm{N}$ as urea and $100 \mathrm{~kg} \mathrm{ha}^{-1}$ of $\mathrm{P}_{2} \mathrm{O}_{5}$ as triple superphosphate for both years. Nitrogen topdressing fertilization (as urea) was performed 18 days after rice emergence, according to each treatment. Cultural practices were performed according to standard recommendations for a rice crop to keep the area free from weeds, diseases and insects.

\section{Nutritional status of rice}

Rice leaf samples were collected from the flag leaf at the full blooming stage. Leaves from 50 plants per plot were collected as proposed by Malavolta (2006), washed and then dried under forced-air circulation at $65^{\circ} \mathrm{C}$ for $72 \mathrm{~h}$ before grinding and analyzing the samples for chemical composition. The concentrations of $\mathrm{N}, \mathrm{P}, \mathrm{K}, \mathrm{Ca}, \mathrm{Mg}, \mathrm{S}, \mathrm{Cu}, \mathrm{Zn}$, $\mathrm{Fe}$ and $\mathrm{Mn}$ were determined using the methods described by Malavolta et al. (1997).

\section{Shoot dry biomass}

Rice shoots of $1.0 \mathrm{~m}$ from one of the rows in each plot were sampled at the full blooming stage. The shoots were washed in water and then dried in a forced air circulation oven at 65 o $C$, then weighed to determine the shoot dry mass content.

\section{Yield components and grain yield}

Rice harvesting was carried out by hand after physiological maturity (March 30, 2016 and March 21 $1^{\text {st }}, 2017$ ) of the grain in the usable area of each plot. Plots were evaluated for the number of panicles $\mathrm{m}^{-1}$, which was determined by counting the number of panicles within $1.0 \mathrm{~m}$ of one of the rows in the useful area of each plot; number of grains per panicle was determined by counting the number of grains in 10 panicles, randomly sampled in the usable area and divided by 10; the mass of 1000 grains was randomly evaluated by collecting and weighing 1000 grains from each plot, corrected to a water content of $13 \%$; and the grain yield was determined by weighing the harvested grain of each plot, corrected to $13 \%$ of the water content and converted to $\mathrm{kg}$ $\mathrm{ha}^{-1}$.

\section{Nutrient content in grains}

In each plot, one sample of $100 \mathrm{~g}$ of grains was taken for nutrient analysis. The grains were ground and analyzed to

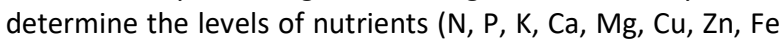
and $\mathrm{Mn}$ ) according to the methodology proposed by Malavolta et al. (1997).

\section{Statistical analysis}

For the statistical analysis, the SAS Statistical Software, SAS Institute, Cary, NC, USA (SAS, 1999) was used. In qualitative variables (upland rice yield components, grain yield, nutrient concentration in leaves and grains), data was subjected to an analysis of variance, and when the $\mathrm{F}$ test proved significant, the data was compared by a Tukey test at $p<0.05$. In the quantitative variables ( $\mathrm{N}$ rates), results were subjected to regression analysis when $p<0.05$.

\section{Conclusion}

Our results concluded that the use of diazotrophic bacteria did not increase nutrient contents in leaves and yield and yield components in grain yield of upland rice. The absence of positive results due to $\mathrm{N}$ application should be attributed to the high level of soil organic matter, which inhibits effects of bacteria. On the other hand, increasing rates of $\mathrm{N}$ enhanced $\mathrm{N}, \mathrm{P}, \mathrm{K}, \mathrm{Ca}, \mathrm{Mg}, \mathrm{S}, \mathrm{Cu}$ and $\mathrm{Mn}$ in leaves, $\mathrm{N}, \mathrm{P}, \mathrm{Ca}$, $\mathrm{Cu}$ and $\mathrm{Fe}$ in the grains, and biomass, panicle per meter, grain per panicle and grain yield of upland rice.

\section{Acknowledgements}

Thanks to the National Council for Scientific and Technological Development (CNPq) for a research award to the first author.

\section{References}

Ahemad M, Kibret M (2014) Mechanisms and applications of plant growth promoting rhizobacteria: Current perspective. J King Saud Uni. 26:1-20.

Claessen MEC (1997) Manual for methods of soil analysis, 2nd edn. Embrapa Solos, Rio de Janeiro, Brazil.

CONAB (2017) Grãos - 10 levantamento da safra 2016/2017, Julho/2016. Available at: http://www.conab.gov.br/OlalaCMS/uploads/arquivos/17 
$07 \quad 1211 \quad 1701$ boletim graos julho 2017.pdf Acessed on: July $13^{\text {th }}, 2017$.

Dobermann CM, Dawe D, Roetter RP, Cassman KG (2000) Reserval of rice yield decline in a long-term continuous cropping experiment. Agron J. 92:633-643.

Fageria NK (2009) The Use of Nutrients in Crop Plants. CRC Press, Boca Raton.

Fageria NK (2014) Nitrogen management in crop production. CRC Press, Boca Raton.

Fageria NK, Moreira A, Coelho AM (2011) Yield and yield components of upland rice as influenced by nitrogen sources. J Plant Nutr. 34:361-370.

Fageria NK, Slaton NA, Baligar VC (2003) Nutrient management for improving lowland rice productivity and sustainability. Adv Agron. 80:63-152.

FAOSTAT (2017) Production: Crops. Available at: $<$ www.faostat.fao.org>. Acessed on: April $29^{\text {th }}, 2017$.

Fidelis RR, Rodrigues AM, Silva GF, Barros HB, Pinto LC, Aguiar RWS (2012) Nitrogen efficiency on upland rice genotypes. Pesqui Agropecu Trop. 42:124-128.

Gitti DC, Arf O, Portugal JR, Corsini DC, Rodrigues RAF, Kaneko FH (2012) Cover crops, nitrogen rates and seeds inoculation with Azospirillum brasilense in upland rice under no-tillage. Bragantia. 71:509-517.

Guimarães SL, Baldani VLD (2013) Rice production inoculated with diazotrophic bacteria marked with induced resistance to the antibiotic streptomycin. Rev Cienc Rural. 56:125-132.

Guimarães SL, Campos DTS, Baldani VLD, Jacob-Neto J (2010) Diazotrophic bacteria and nitrogen fertilization in rice cultivars. Rev Caatinga. 23:32-39.

Heinemann $A B$, Dingkuhn $M$, Luquet $D$, Combres JC, Chapman S (2008) Characterization of drought stress environments for upland rice and maize in central Brazil. Euphytica. 162:395-410.

Hernandes A, Buzetti S, Andreotti M, Arf O, Sá ME (2010) Doses, sources and periods of nitrogen application in rice cultivars. Cienc Agrotec. 34:307-312.

Kumar V, Ladha JK (2011) Direct seeding of rice: recent developments and future research needs. Adv Agron. 111:297-396

Kuss AV, Kuss VV, Lovato T, Flôres ML (2007) Nitrogen fixation and in vitro production of indolacetic acid by endophytic diazotrophic bacteria. Pesqui Agropecu Bras. 42:1459-1465.

Ladha JK, Pathak H, Krupnik TJ, Six J, Van Kessel C (2005) Efficiency of fertilizer nitrogen in cereal production: Retrospects and prospects. Adv Agron. 87:85-156.

Lopes RA, Salatier B, Teixeira Filho M, Carvalho M, Benett S, Gredson S, Arf MV (2013) Doses, sources and application times of nitrogen on rice grown in no tillage system. Rev Caatinga. 26:79-87.

Malavolta E, Vitti GC, Oliveira AS (1997) Avaliação do estado nutricional de plantas: princípios e aplicações. Associação Brasileira para Pesquisa da Potassa e do Fosfato, Piracicaba.

Malavolta E (2006) Manual de nutrição de plantas. Agronômica Ceres, São Paulo.

Martins RM, Jantalia CP, Polidoro JC, Batista JN, Alves BJR, Boddey RM, Urquiaga S (2015) Nitrous oxide and ammonia emissions from $\mathrm{N}$ fertilization of maize crop under no-till in a Cerrado soil. Soil Till Res. 151:75-81.
Nascente AS, Lanna AC (2016) Straw and early nitrogen fertilization affect soil properties and upland rice yield. Pesqui Agropecu Trop. 46:284-291.

Nascente AS, Filippi MCC, Lanna AC, Souza ACA, Silva-Lobo VL, Silva GB (2017) Biomass, gas exchange, and nutrient contents in upland rice plants affected by application forms of microorganism growth promoters. Environ Sci Pollut R. 24:2956-2965.

Pereira JAR, Cavalcante VA, Baldani JI, Dobereiner J (1988) Field Inoculation of sorghum and rice with Azospirillum spp. and Herbaspirillum seropedicae. Plant Soil. 110:269274.

Pérez-Montaño $F$, Alías-Villegas C, Bellogín RA, Cerro $P$, Espuny MR, Jiménez-Guerrero I, López-Baena FJ, Ollero FJ, Cubo T (2014) Plant growth promotion in cereal and leguminous agricultural important plants: From microorganism capacities to crop production. Microbiol Res. 169:325-336.

Prakamhang J, Minamisaw K, Teamtaisong K, Boonkerd N, Teaumroong N (2009) The communities of endophytic diazotrophic bacteria in cultivated rice (Oryza sativa L.). Appl Soil Ecol. 42:141-149.

Reis AFB, Almeida REM, Chagas Junior AF, Nascente AS (2017) Effect of cover crops on soil attributes, plant nutrition, and irrigated tropical rice yield. Rev Caatinga. 30:837-846.

Sabino DCC, Ferreira JS, Guimarães SL, Baldani VLD (2012) Diazotrophs as promoting the initial development of rice seedling. Encicl Biosfera. 8:2337-2345.

Santos AB, Stone LF, Vieira NR (2006) A cultura do arroz no Brasil, 2nd edn. Embrapa Arroz e Feijão, Santo Antônio de Goiás.

SAS Institute (1999) Procedure guide for personal computers. Version 5. SAS Institute: Cary.

Silva RO, Barioni LG, Zanett AT, Eory V, Toop CFE, Fernandes FA, Moran D (2016) Developing a nationally appropriate mitigation measure from the greenhouse gas GHG abatement potential from livestock production in the Brazilian Cerrado. Agr Syst. 140:48-55.

Sousa DMG, Lobato E (2004) Cerrado: correção do solo e adubação, 2nd edn., Embrapa Cerrados, Brasília.

Sturz AV, Nowak J (2000) Endophytic communities of rhizobacteria and the strategies required to create yield enhancing associations with crops. Appl Soil Ecol. 15:183190.

Vogel GF, Martinkoski L, Martins PJ, Bichel A (2013) Agronomic performance of Azospirillum brasilense in rice culture: A Review. Rev Agron Meio Amb. 6:67-578.

Yoshida S (1981) Fundamentals of rice crop science, 1edn IRRI, Laguna.

Zaki Safi-naz S (2016) Effect of compost and nitrogen fertilization on yield and nutrients uptake of rice crop under saline soil. Modern Chem Applic. 4:1-3.

Zhang G, Zeng Y, Chen M, Yu Z, Yu H, Li Y, Yu H (2011) Effects of physico-chemical parameters on the bacterial and fungal communities during agricultural waste composting. Biores Techn. 102:2950-2956. 